\title{
Traditional Chinese Culture and Tourism Management
}

\author{
Chen Chao \\ Xiang Hua-ping \\ Jiangxi College Of Foreign Studies
}

\begin{abstract}
Tourism management is a newly emerged branch of modern management science, which has both the universal properties of management science and its own characteristics. In this paper, it starts from the relationship between traditional Chinese culture and tourism management to investigate the effect of traditional Chinese culture on tourism management based on human competition by specifically combining them together so as to make rational explanations. Culture lies in human's behaviors, which indicates the deposit of traditional ethnic culture. Therefore, it is helpful for establishing tourism management culture from the perspective of traditional culture by investigating particular ethnic mental qualities and values, which can provide references of traditional culture for modern tourism management.

Keywords-China; traditional culture; tourism management
\end{abstract}

\section{INTRODUCTION}

The main management objects of tourism enterprises are people. Besides material satisfaction, people also need mental and psychological demand. The management object is human while human is the carrier of traditional culture, and a nation's cultural tradition is mainly expressed by human's behaviors. In China, a country with over five-thousand civilized history, traditional culture has a deep and huge influence on national citizens. Both the personalities and psychologies of national citizens are shaped by traditional culture. Most employees in tourism enterprises are Chinese citizens, which means that management in tourism enterprises will be surely affected by traditional culture.

Modern tourism is a special industry which is established by reception and service, so service quality of employees working in the front line can directly affect the survival and development of enterprises. The secret of success in such an industry lies in how to meet tourists' changing demands, which requires operators to effectively manage the human resources so as to form a economic resource that can offer timely reaction and service to tourists. It is a major project to maximize the employees' potentials and effectively mobilize their working initiative, activeness and creativity so that individuals can internalize the external stimulation into conscious awareness and behaviors.

\section{THE EFFECT OF TRADITIONAL CHINESE CULTURE ON TOURISM MANAGEMENT}

\section{A. The management should be carried out with human as the center.}

The people-oriented management concept in today's tourism enterprises is consistent with traditional Chinese culture which values human. The ancient scholar Xunzi once said that humans can master the natural rules and use them to serve humans, which advocated the importance of human beings. There are also some other ancient sayings, for example, a nation can only be stable with unified people. People can help to establish a state, and they can also overthrow a state, which indicated the importance of people in terms of politics.

\section{B. An ideal enterprise with harmonious working atmosphere}

The fine quality of service in tourism enterprises is related to popularity and fortune. An enterprise with great popularity can bring it with lots of fortune. As for tourism enterprises, the harmonious interpersonal relationship and communication is determined by inside cohesion fundamentally. The concepts of humanity, love and harmony in traditional Chinese culture can help to establish and develop a harmonious interpersonal relationship inside the tourism enterprise so as to form a powerful cohesion. According to traditional culture, Chinese people have always advocated a harmonious atmosphere. Thus, people should get along well with others with humanity and morality.

\section{THE EFFECT OF CHANGING CHINESE SOCIAL VALUES ON TOURISM MANAGEMENT}

Since the reform and opening up, affected by western culture, the traditional values system is collapsing with an emergence of plural values. During the restructure of values system, traditional values are coexistent with individualized values which emphasizes self feelings and material pursuits without lofty ideas. Tourism has been early developed since the reform and opening up, which is more easily affected by western values, and employees may produce plural values more easily. Individuals' recognition on an organization's vision can only be realized by integrating plural values into uni-value view so as to realize self improvement and enhance cohesion. As for tourism enterprises, they should main consider the following issues. 


\section{A. Employees' belongings under the new circumstance}

The transition of the time has made modern people more and more independent with weaker attachment to enterprises. Therefore, some people doubted some if employees' loyalty and belongings are still required or not. Self improvement is a necessary demand for individuals under a society with high competition; however, loyalty still needs to be advocated inside an organization. In order to achieve this goal, the enterprise should establish a management culture with high cohesion.

\section{B. Creative enterprise management culture}

In order to give play to personal abilities and meet individual's sense of achievement, enterprises should create management cultures suitable for the goals. As an organization, it should make constant innovations since innovation is the soul of a nation as well as the source of an enterprise's vitality. Innovation is not only technological innovation, but it also includes innovation on working methods, production tools and skills as well as marketing.

\section{CONSTRUCTION OF THE THEORIES BETWEEN TRADITIONAL CHINESE CULTURE AND TOURISM MANAGEMENT}

Tourism management is a cause with deep cultural connotation. In 21st century, tourism management

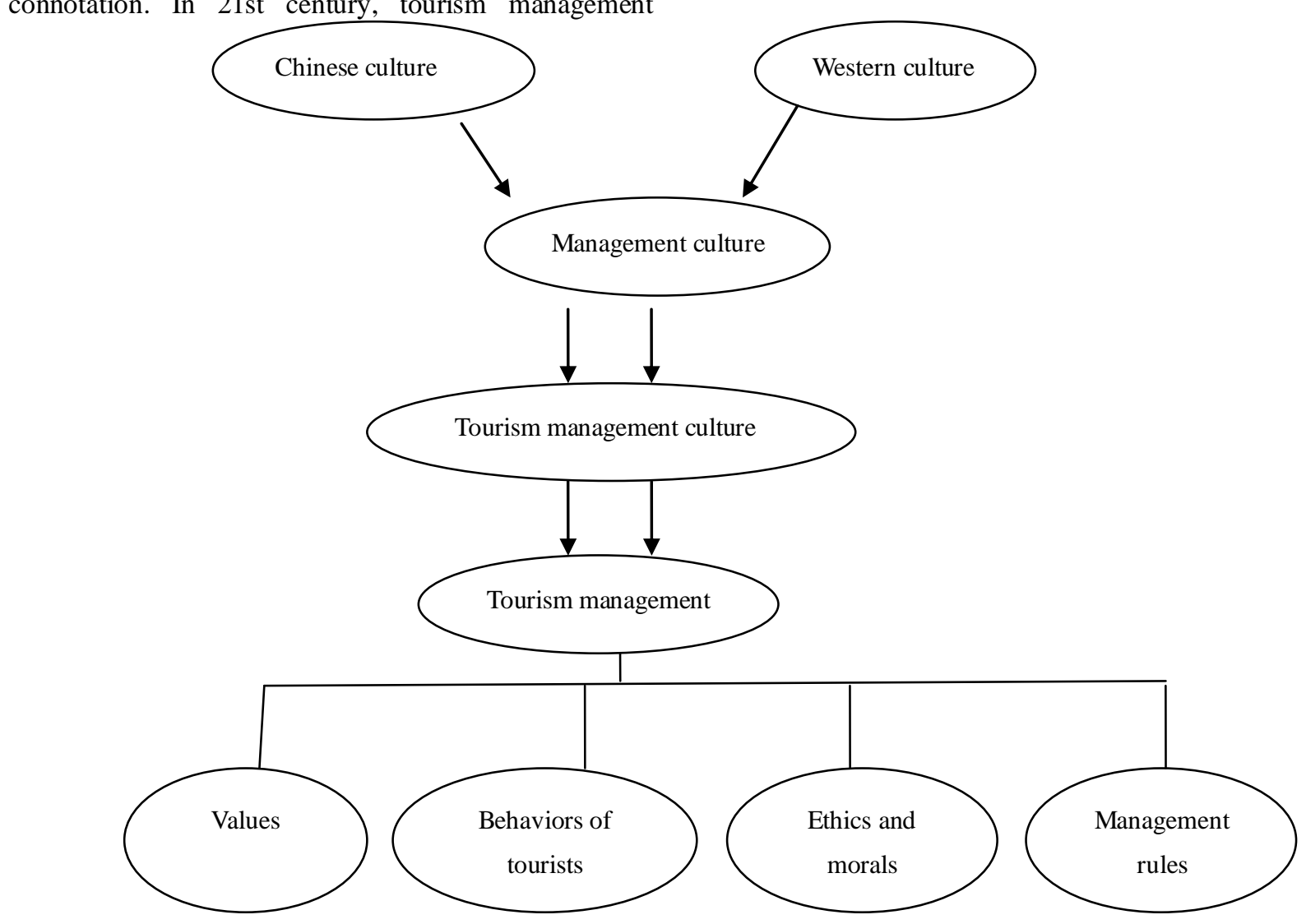

Figure 1. Structure map of tourism management culture should carefully absorb the essence of traditional Chinese culture so as to establish individualized management culture. By this way, theoretical study on tourism management culture can make a practical guiding difference on realistic tourism management. Tourism cause is a green industry as well as sunrise industry in the new century, which has extremely broad prospect for its development. Our tourism management can only establish its own characteristic tourism management culture by absorbing traditional culture and foreign culture so as to promote the development of tourism cause.

The generation of management ideas and the formation of management culture are affected by economic basis and restricted by social, political and cultural traditions. The effect can't be sound by learning from foreign management theories alone without consideration of national cultural traditions. Instead, tourism enterprises should absorb rational elements of traditional culture while learning from foreign advanced management theories and ideas so as to truly form tourism management theories suitable for our country. The structure map of tourism management culture is shown below. 
This sketch has expressed the significance of culture on tourism management intuitively. The effect of Chinese-western culture on tourism management culture is macro overall effect instead of influence on partial behaviors. Such management culture with deep cultural connotation plays an even more active role in the sub-management system with deeper cultural deposit.

\section{CONCLUSION}

With the development of society, China's social value orientation has also been change to some extent, which has made an effect on tourism management ideas, tourism management culture as well as related tourism management causes. Only if we can fully recognize and master the laws, we can achieve better effect during the construction of tourism management and theories.

Culture is a soft management, which can affect people's deeper psychology gradually. Tourism enterprises should create a sound external and internal environment with coexistence of competition and harmony by absorbing essence from traditional Chinese culture and building orders for tourism management. Thus a harmonious atmosphere can be built and internal resources can be rationally allocated with maximum effect. If an enterprise adopts a people-oriented management culture by giving importance to human's personality and making full use of human's positive factors, then the overall management level will be promoted with full use of resources and active factors.

\section{REFERENCES}

[1] Koh K. Designing the Four-Year Tourism Management Curriculum: A Marketing Approach[J]. Journal of Travel Research, 1995, 34:68-72.

[2] Northcote J, Macbeth J. Conceptualizing yield: Sustainable Tourism Management[J]. Annals of Tourism Research, 2006, 33(1):199-220.

[3] Frey N, George R. Responsible tourism management: The missing link between business owners' attitudes and behaviour in the Cape Town tourism industry[J]. Tourism Management, 2010, 31(5):621-628.

[4] Shaw G, Bailey A, Williams A. Aspects of Service-dominant Logic and Its Implications for Tourism Management: Examples from the Hotel Industry[J]. Tourism Management, 2011 , 32(2):207-214

[5] Rizzo I, Cuccia, Cuccia. Tourism seasonality in cultural destinations: Empirical evidence from Sicily, in Tourism Management, vol. 32 n. 3, pp. 589-95. (co-author with T. Cuccia).[J]. Tourism Management, 2011, 32:589-595.

[6] Li Y, Wall G. Ethnic tourism: A framework and an application. Tourism Management, 30(4), 559-570[J]. Tourism Management, 2009, 30:559-570.

[7] David Mcadam. The value and scope of geographical information systems in tourism management.[J]. Journal of Sustainable Tourism, 1999, 7(1):77-92.

[8] Yeoman I, Lennon J J, Blake A, et al. Oil Depletion: What Does This Mean for Scottish Tourism. Tourism Management. Vol 25, No 5[J]. Tourism Management, 2007, 1354-1385:1354-1365.

[9] Mclellan R. Tourism Management Dynamics: Trends, Management and Tools'[J]. Tourism \& Hospitality Research, 2006, 6(2): 192-195.

[10] Hall D. Rural tourism management: sustainable options conference[J]. International Journal of Tourism Research, 2000, 2(4):295-299.

[11] Lew A A. Tourism management on American Indian lands in the USA.[J]. Tourism Management, 1996, 17(5):355-365.

[12] Goodwin H. Taking responsibility for tourism : responsible tourism management[M]// Goodfellow, 2011:299-300. 